\title{
THE IMPACT OF INTRAPRENEURSHIP STRATEGY ON BUSINESS PERFORMANCES OF ITALIAN COMPANIES
}

\author{
Vojislav Babic, PhD \\ University of Belgrade, Institute for Sociological Research \\ 18 CikaLjubina street, 11000 Belgrade, Serbia \\ Phone: +38163334067, e-mail: babic.voja@gmail.com \\ Sinisa Zaric, PhD \\ University of Belgrade, Faculty of Economics \\ 6 Kamenicka street, 11000 Belgrade, Serbia \\ Phone: +38163254525, e-mail: sinisha.zaric@gmail.com \\ Rossana Piccolo, PhD \\ University of Campania "Luigi Vanvitelli", Caserta, Italy \\ e-mail: rossana.piccolo@unicampania.it
}

\section{ABSTRACT}

Intrapreneurship is a decentralized management strategy applied in large and mediumsized companies. The strategy enables employees to use their entrepreneurial skills for the benefit of both the company and the employee. Talented employees get the opportunity to create ideas, undertake innovative ventures, to experiment, to gain access to financial and other resources in order to encourage innovative change and results. The creator of the idea was the Pinchot couple in 1978, but to this day, the concept has undergone several evolutionary waves (Antoncic, 2020). The intrapreneurship strategy positively affects the agility in the company, raises efficiency, has a positive effect on the team spirit, increases productivity, reduces costs and raises profitability. The main goal of the paper is to analyze the level of intrapreneurship presence in large and medium-sized companies in the Italian region of Campania. The influence of intrapreneurship parameters on companies' business indicators is also measured. An instrument for measuring intrapreneurship was created for the needs of paper. The instrument measures: the presence of autonomous teams in the company, the possibility of taking business initiative, the speed of access to resources for testing purposes and realization of new business ideas, encouraging risk-taking with the aim of realizing business ideas, the mobility of resources within the company, the degree of management tolerance in order to realize new business ideas of employees, the presence of rewards, the level of management support at all levels, the number of hierarchical levels in the company and the role of crowdsourcing in the development of internal entrepreneurship. After factor and regression analysis, Factor 1 has a dominant impact on all three business indicators, while Factor 2 has a smaller but a statisticallysignificant impact on the company's volume of business and investments.

Keywords: intrapreneurship, companies, Italy, Campania, business performances 


\section{INTRODUCTION}

Intrapreneurship is a decentralized management strategy applied in large and mediumsized enterprises. The strategy allows employees to use their entrepreneurial skills to the benefit of the company and employees. Talented employees have the opportunity to create ideas, undertake innovative ventures, experiment, gain access to financial and other resources in order to drive innovative change and results. In the era of Industrial Revolution 4.0, the intrapreneurship strategy represents the important potential for creating innovation and stimulating investments and growth, which can contribute to overcoming the negative impact of the COVID-19 pandemic on the company's business and the entire economy. The paper analyzes the achievements of intrapreneurship in large and mid-sized companies in the Italian region of Campania. Italy is a country that has a foundational role in the development of capitalism, of modern economic growth, and thus of any modernity, including also contemporary management strategies (Fredona \& Reinert, 2020). The rich and meaningful business practice of such a country as Italy, which has stretched from the time of the city-states of medieval times and Renaissance to the present day, is always a suitable place to start interesting research on the application and effectiveness of managerial concepts in a company's life. From the methodological aspect, the econometric method was used in the research. A questionnaire was used as an instrument for data collection. The hypothesis that intrapreneurship strategy influences the change of three business indicators of the company was examined. The initial hypothesis was operationalized as follows:

$\mathrm{H} 1$ : intrapreneurship strategy influences the change in the volume of the company's business

$\mathrm{H} 2$ : intrapreneurship strategy influences the change of the company's investment trend

H3: intrapreneurship strategy affects the change of wages in the company.

\section{LITERATURE REVIEW}

The preliminary concept on intrapreneurship was discussed for the first time in Gifford and Elizabeth Pinchot's text in 1978.The concept has survived several evolutionary waves, but this paper will rely on contemporary literature in this field. The concept of intrapreneurship is conducted in companies to bring profitability and strategic renewal, to encourage innovation, to obtain knowledge about future revenue streams, and to achieve international success (Hornsby, Kuratko \& Zahra, 2002). According to Peter van der Sijde et al. (2013), the concept of intrapreneurship is often carried out in big companies. In micro and small companies, the boundaries between traditional business and intrapreneurship have become confusing. Intrapreneurship is a system that puts employees in the role of entrepreneurs within the company. Intrapreneurs are motivated, proactive people ready to take the initiative aimed at creating innovative products and services (Radman, 2019: 2). There are many benefits of the intrapreneurship strategy, of which the following stand out: 1 . generating new business growth, 2 . creating innovation, 3. leadership, 4 . intrapreneurship accelerates and manages changes, and, 5. intrapreneurship is a springboard for engaging employees in work that is challenging and meaningful (Radman, 2019: 3). 
Burgelman (2016) sees intrapreneurship as a manifestation of the irrepressible individual drive to innovate in organizational contexts. In order to achieve the full effectiveness of intrapreneurship, there is a need to be managed as an integral part of the strategy-making process. The strategy involves fostering cooperation with other parts of the company throughout the development process.

From creativity to resilience, from risk appetite to communication skills... These are the characteristics that distinguish intrapreneurs from other employees by the set of qualities that force them to take action. But an intrapreneur is not born. It is necessary to identify these talents and create the conditions for them to express themselves (CavaIlaro \& Gaschi, 2019). When asked who the intrapreneur is, the authors answer that it is an employee who possesses an entrepreneurial and creative mindset, that is, those who are capable of generating new ideas and developing new solutions within the company perimeter: a figure, therefore, of importance in the innovation processes. The ideal intrapreneur is a superhero who expresses at least 10 key skills typical of entrepreneurs, and is able to apply and enhance them in a corporate context: 1 . creativity and courage, 2. he/ she is a good observer, 3. proactivity, 4 . he/ she can manage uncertainty, 5 . he/ she has a good risk tolerance, 6 . he/ she is an experimenter, 7. he/ she knows how to face and accept mistakes, 8 . he/ she is excellent at communication, 9. he/ she is able to collaborate, and, 10. he/she is resilient. Intrapreneurs (and entrepreneurs) are not born, even though passion and persistence can be the in the genes of some people. It is necessary to develop the entrepreneurial skills described above, which are nowadays increasingly relevant to companies competing in deeply transforming markets (ibid.). Kruger and Nel (2019) state that the best way to direct an intrapreneur is to imagine their unit as a stand-alone business. Doing this type of business implies the existence of a certain budget for the implementation of intrapreneurs' ideas. As for intrapreneurs, it is important to deliver a quality product at the agreed time. The authors also point out that cashflow and profitability are crucial.

According to Elert and Stankula (2020), intrapreneurs play a critical role in innovation. The values of intrapreneurship depend on the characteristics of the firm as well as the societal reward structures that intrapreneurs face. Ideally, the social rules for rewarding intrapreneurship are such that they bring benefits to the economy. However, there are cases when intrapreneurship benefits companies, but not society and vice versa. The authors offered a systematic overview of how a company and firm rules affect the creation of various intrapreneurship issues (ibid.). Speaking about the differences between entrepreneurship and intrapreneurship, Antoncic (2020) points out that intrapreneurs operate within an existing organization. Therefore, they need to cooperate with managers and owners and therefore have a less pronounced need for independence than entrepreneurs.

Mumford et al. (2020) explore the key intrapreneur's skills needed to translate creative ideas into innovative products. Besides, the authors explore how company policy contributes to the development and application of skills as well as encouraging intrapreneurs to persevere in the realization of initial ideas.

In a sample of 510 employees in 5 firms, Itzkovich et al. (2021) investigate the impact of job satisfaction and job insecurity driven by incivility on intrapreneurial behavior. Based on the results, incivility decreases intrapreneurial behavior, mediated by job satisfaction and job insecurity. Besides, the relationship between job satisfaction and job insecurity, 
and intrapreneurial behavior distinguishes unionized employees from employees who are not members of the unions.

In a sample of 109 employees in 50 Indian companies Kumar and Parveen (2021) investigated the influence of factors that help in enabling the intrapreneurial behaviour amongst the employees. According to the results, organizational characteristics (communication, formal controls, management support, resources and rewards) and environmental characteristics (dynamism, technological opportunities, perceived industry growth, demand for new products, competitive rivalry) are positively related to the intrapreneurial behavior among employees. Besides, it was concluded that the self-renewal behavior was considered as an important intrapreneurial activity for the respondents. Guven (2020) pointed out the importance of strategic intrapreneurship for discovering innovation and achieving a competitive advantage in the market. Using quantitative and qualitative analysis, the author determined that the participants have a high level of strategic intrapreneurship behavior.

Duradoni and Di Fabio (2019) analyzed the relationship between extraversion, intrapreneurial self-capital, and innovative behavior, using a sample of 120 Italian workers. The authors used the mediation model to assess the effects of extraversion on innovative behavior and innovative implementation behavior through intrapreneurial self-capital. Based on the mediation model, intrapreneurial self-capital is correlated with both workers' innovative behavior and innovative implementation behavior. Divakara and Surangi (2021) prove that the link between intrapreneurship and entrepreneurship positively affects organizational growth and the dyadic effect related to thrift, productivity and efficiency of internal operation in the medium scale manufacturing industry of Sri Lanka.

\section{RESEARCH DESIGN}

\subsection{Sample and Data description}

The sample included 67 large and mid-sized companies in the Italian region of Campania. When planning the sample, care was taken to ensure a credible ratio of large companies and mid-sized companies in Campania (OECD, 2020). Selection of companies was made from the list of Local business directory of Campania (Businessfield, 2020) by using the simple random sample method without repetition.

For the purposes of the research, a measuring tool (MT) is created that measures the levels of intrapreneureship in companies. The MT consists of 11 questions that measure the attendance of autonomous teams in the company, the possibility of taking business initiative, the speed of access to resources for testing purposes and realization of new business ideas, encouraging risk with the aim of realizing business ideas, the presence and mobility of resources within the company, the degree of management tolerance in order to realize new business ideas of employees, the presence of rewards, the level of management support at all levels, the number of hierarchical levels in the company, and the role of crowdsourcing in the development of internal entrepreneurship. As a methodological instrument for data collection, a written questionnaire with four-step Likert's scales was used. When it comes to business indicators, the company's business volume, investment trend and wages' level were measured. Likert scales were used for measurement. As for 
the volume of business, the respondents were asked the following question: "Compared to 2019, the volume of business of your company has: significantly decreased, decreased slightly, remained unchanged, increased slightly or increased much"? In this way, we have tried to gain an insight into the long-term business volume due to the greater research accuracy. As for the investment trend, respondents were asked the following question: "In the next 6 months, are you planning to: reduce, leave unchanged or increase your investment in the business"?

Finally, the respondents were asked the following question: "In relation to 2019, your wages have, realistically speaking: significantly decreased, slightly decreased, remained the same, slightly increased or significantly increased"? The questionnaire was given to managers of the selected companies.

\subsection{Factorial analysis}

Eleven variables for measuring intrapreneurship level were processed by the factor analysis technique. The initial idea was to isolate a number of complex factors that would later be linked to the company's business variables. The analysis starts with the following basic model:

$$
X_{i}=a_{i 1} F_{1}+a_{i 2} F_{2}+a_{i 3} F_{3}+a_{i 4} F_{4}+e_{i}
$$

Where $X$ is the value of the factor score, $i$ the ordinal number of the variable, $F$ represents the factors, $a$ stands for factor loadings and $e$ is the specific factor related only to the given variable. Factor analysis using the maximum likelihood extraction method was used in the study (Millar, 2011). The extraction algorithm in the maximum likelihood variant (Field, 2005) is set so that the maximum likelihood of the options $\Lambda$ and $\psi 2$ is obtained by minimizing the expression 2:

$$
F=\operatorname{tr}\left[\left(\Lambda \Lambda^{\prime}+\psi 2\right)-1 R\right]-\log \left|\left(\Lambda \Lambda^{\prime}+\psi 2\right)-1 R\right|-p
$$

and according to $\Lambda$ and $\psi 2$ respectively, where $p$ represents the number of variables, $\Lambda$ factor loading matrix, and $\psi 2$ diagonal matrix of unique variance. Minimizing $F$ is done via a two-step logarithm. In the first step, the conditional minimum for $F$ is calculated, for the given $y$. In this way, the function $f(\psi)$ is obtained and it is numerically minimized by the Newton-Raphson method (Field, 2005; Ahmad et al., 2007). As all the necessary conditions of Kaizer-Mayer and Bartlett's test (Table 1) for continuing the analysis were met (Field, 2005), the factor analysis procedure started.

\section{Table 1. Kaizer-Mayer and Bartlett's test}

\begin{tabular}{|l|l|c|}
\hline \multicolumn{2}{|l|}{ Kaiser-Meyer-Olkin Measure of Sampling Adequacy. } & 0.825 \\
\hline \multirow{2}{*}{ Bartlett's Test of Sphericity } & Approx. Chi-Square & 668.794 \\
\cline { 2 - 3 } & df & 55 \\
\cline { 2 - 3 } & Sig. & 0.000 \\
\hline
\end{tabular}

Source: Authors 
Following the varimax rotation, two significant complex factors were identified. Factor loadings are shown in Table 3. Seen cumulatively, two factors explain $71.79 \%$ of the total variance. Generally, the minimum value of factor loadings considered in studies is \pm 0.3 while factor loadings with values \pm 0.70 are considered indicative for a well-defined structure, and they are a true target of factor analysis (Hair et al., 2010). The cells with significant factor loadings in Table 2 are colored gray:

Table 2. Rotated Factor Matrix ${ }^{a}$

\begin{tabular}{|c|c|c|}
\hline & \multicolumn{2}{|c|}{ Factors } \\
\hline & 1 & 2 \\
\hline The work of autonomous and functional teams & 0.814 & 0.384 \\
\hline Are employees in your company allowed to take a business initiative? & 0.630 & 0.380 \\
\hline $\begin{array}{l}\text { Are employees in your company provided with quick and informal } \\
\text { access to resources for testing purposes and realization of new } \\
\text { business ideas? }\end{array}$ & 0.645 & 0.657 \\
\hline $\begin{array}{l}\text { Does your company encourage employees to take risks in order to } \\
\text { realize new business ideas? }\end{array}$ & -0.169 & 0.909 \\
\hline Does your company have the resources to develop new business ideas? & 0.713 & 0.277 \\
\hline $\begin{array}{l}\text { What is the possibility for employees to use the resources of other } \\
\text { business units in your company, in order to implement new business } \\
\text { ideas? }\end{array}$ & 0.568 & 0.466 \\
\hline $\begin{array}{l}\text { To what extent is your organization willing to tolerate mistakes in order } \\
\text { to realize new business ideas of employees? }\end{array}$ & 0.555 & 0.633 \\
\hline $\begin{array}{l}\text { Does your company have a system for rewarding new business ideas } \\
\text { and employees' results? }\end{array}$ & 0.768 & 0.189 \\
\hline Is there support from management at all levels in your company? & 0.308 & 0.734 \\
\hline $\begin{array}{l}\text { In the past } 5 \text { years, has the number of hierarchical levels changed in } \\
\text { your company? }\end{array}$ & -0.607 & -0.715 \\
\hline $\begin{array}{l}\text { Do you know the role of crowdsourcing in the development of internal } \\
\text { entrepreneurship? }\end{array}$ & 0.909 & -0.210 \\
\hline
\end{tabular}

Extraction Method: Maximum Likelihood

Rotation Method: Varimax with Kaiser Normalization ${ }^{a}$

a. Rotation converged in 3 iterations

Source: Authors

Factor 1 is saturated with the following factor loadings: the work of autonomous and functional teams, the possibility of taking business initiative, quick and informal access to resources for testing purposes and realization of new business ideas, the presence and mobility of resources within the company, the degree of management tolerance in order to realize new business ideas of their employees, the presence of rewards, the level of management support at all levels, the number of hierarchical levels in the company, and the role of crowdsourcing in the development of internal entrepreneurship.

Factor 2 included the following loadings: The work of autonomous and functional teams, the possibility of taking business initiative, quick and informal access to resources for testing purposes and realization of new business ideas, encouraging the employees to take risks in order to realize new business ideas, mobility of resources within the com- 
pany, the degree of management tolerance in order to realize new business ideas of employees, the level of management support at all levels, and the number of hierarchical levels in the company.

Having in mind that the factor loadings with the values of \pm 0.70 are considered indicative for a well-defined structure, they are the main carriers of the factor characteristics. The following characteristics are observed in the structure of factors. Factor 1 contains four loadings with values higher than 0.70: crowdsourcing (0.909), the work of autonomous and functional teams (0.814), rewarding system (0.768), and resources for developing new ideas (0.713). As it can be seen, these factor loadings are characterized by the organizational-financial aspect. On the other hand, in the Factor 2 structure, three loadings with values above and below \pm 0.70 are observed. These are: encouraging employees to take the risks (0.909), the level of management support (0.734), and the number of hierarchical levels in the company $(-0.715)$. The organizational-psychological nature is common to these factor loadings.

\subsection{Model and findings}

In order to measure the impact of intrapreneurship on the company's business indicators, the following model was created:

$$
y_{i}=B_{0}+b_{1} f_{i 1}+b_{2} f_{i 2}+\varepsilon_{i}
$$

In the first case, the impact of scores (isolated by factor analysis) on the company's business volume was measured.

Where, for $i=n$ observations:

$y_{i}=$ dependent variable (company's volume of business)

$b_{0}=y$ intercept (constant)

$B_{1}=$ slope coefficient of predictor $f_{i 1}$

$B_{2}=$ slope coefficient of predictor $f_{i 2}$

$f_{i 1} f_{i 2}=$ the independent variables (regression factor scores 1 - 2)

$\varepsilon_{i}=$ random error

The results show significant values for all three $\mathrm{R}$ coefficients (Table 3 ). Due to the limitations of the smaller sample, the adjusted coefficient $R^{2}$, which has more severe criteria, is used in the analysis. Based on the value of adjusted $\mathrm{R}^{2}$, a set of two-factor scores explains $65.7 \%$ of the variability of 'company's volume of business'.

Table 3. Regression model summary (Dependent variable: volume of business)

\begin{tabular}{|c|c|c|c|c|}
\hline Model & $\mathrm{R}$ & R Square & Adjusted R Square & $\begin{array}{c}\text { Std. Error of the } \\
\text { Estimate }\end{array}$ \\
\hline 1 & $.817^{\mathrm{a}}$ & 0.667 & 0.657 & 0.632 \\
\hline
\end{tabular}


Table 4 shows the contributions by factor scores. Both factor scores have significant contributions to the dependent variable but with a different sign. If the Factor score 1 goes up by one point, the company's volume of business jumps by 0.832 . On the other side, when the Factor score 2 jumps by one point, the dependent variable decreases by -0.385 (Table 4).

Table 4. Coefficients ${ }^{\mathrm{a}}$

\begin{tabular}{|c|c|c|c|c|c|c|}
\hline \multirow{2}{*}{\multicolumn{2}{|c|}{ Model }} & \multicolumn{2}{|c|}{$\begin{array}{l}\text { Unstandardized } \\
\text { Coefficients }\end{array}$} & \multirow{3}{*}{$\begin{array}{c}\begin{array}{c}\text { Standardized } \\
\text { Coefficients }\end{array} \\
\text { Beta }\end{array}$} & \multirow{3}{*}{$\begin{array}{c}\mathrm{t} \\
35.596\end{array}$} & \multirow{3}{*}{$\begin{array}{c}\text { Sig. } \\
0.000\end{array}$} \\
\hline & & \multirow{2}{*}{$\frac{B}{2.746}$} & \multirow{2}{*}{$\begin{array}{c}\text { Std. Error } \\
0.077\end{array}$} & & & \\
\hline \multirow{3}{*}{1} & (Constant) & & & & & \\
\hline & $\begin{array}{l}\text { REGR. factor score } 1 \text { for } \\
\text { analysis } 1\end{array}$ & 0.832 & 0.080 & 0.751 & 10.403 & 0.000 \\
\hline & $\begin{array}{l}\text { REGR. factor score } 2 \text { for } \\
\text { analysis } 1\end{array}$ & -0.385 & 0.081 & -0.345 & -4.782 & 0.000 \\
\hline
\end{tabular}

Source: Authors

Since both factors cause changes in the volume of the company's business, it is concluded that hypothesis $\mathrm{H} 1$ has been confirmed. In the case of the volume of company's business, the growth of Factor 1, which is the bearer of the organizational-financial aspect, leads to an increase in the volume of business. Based on the results of respondents, Factor 2 , which is predominantly psychological-organizational in nature, has an inversely proportional impact on the volume of business. It is likely that the existing encouragement of employees and management support are not at a satisfactory quality level, so this negatively affects the volume of business.

In the second case, the influence of factor scores on the investment trend of the company was measured. The following model was used:

$$
t_{i}=b_{0}+b_{1} f_{i 1}+b_{2} f_{i 2}+\varepsilon_{i}
$$

Where, for $i=n$ observations:

$t_{i}=$ dependent variable (investment's trend)

$B_{0}=y$ intercept (constant)

$B_{1}=$ slope coefficient of predictor $f_{i 1}$

$B_{2}=$ slope coefficient of predictor $f_{i 2}$

$f_{i 1}, f_{i 2}=$ the independent variables (regression factor scores $1-2$ )

$\varepsilon_{i}=$ random error 
Based on the value of adjusted $\mathrm{R}^{2}$, a set of two predictor variables explains $82.1 \%$ of the variability of 'investment's trend' (Table 5):

Table 5. Regression model summary (Dependent variable: investment's trend)

\begin{tabular}{|l|c|c|c|c|}
\hline Model & R & R Square & Adjusted R Square & $\begin{array}{c}\text { Std. Error of the } \\
\text { Estimate }\end{array}$ \\
\hline 1 & $.909^{a}$ & 0.826 & 0.821 & 0.371 \\
\hline \multicolumn{2}{|l|}{ a. Predictors: (Constant), REGR factor score 2 for analysis 1, REGR factor score 1 for analysis 1} \\
\hline
\end{tabular}

Source: Authors

Based on the results, both factor scores have a significant contribution to the investment growth. If the Factor score 1 goes up by one point, investments jump by 0.709 . When the Factor score 2 jumps by one point, investments jump by 0.393 (Table 6). Both factors influence the increase of the investment trend of companies, but Factor 1, which primarily refers to the financial aspect, has a dominant influence.

Table 6. Coefficients ${ }^{\mathrm{a}}$

\begin{tabular}{|c|c|c|c|c|c|c|}
\hline \multirow{2}{*}{\multicolumn{2}{|c|}{ Model }} & \multicolumn{2}{|c|}{$\begin{array}{l}\text { Unstandardized } \\
\text { Coefficients }\end{array}$} & \multirow{3}{*}{$\begin{array}{c}\begin{array}{c}\text { Standardized } \\
\text { Coefficients }\end{array} \\
\text { Beta }\end{array}$} & \multirow{3}{*}{$\begin{array}{c}\mathrm{t} \\
45.828\end{array}$} & \multirow{3}{*}{$\begin{array}{l}\text { Sig. } \\
0.000\end{array}$} \\
\hline & & \multirow[t]{2}{*}{ B } & \multirow[t]{2}{*}{ Std. Error } & & & \\
\hline \multirow{3}{*}{1} & (Constant) & & & & & \\
\hline & $\begin{array}{l}\text { REGR. factor score } 1 \text { for } \\
\text { analysis } 1\end{array}$ & 0.709 & 0.047 & 0.787 & 15.102 & 0.000 \\
\hline & $\begin{array}{l}\text { REGR. factor score } 2 \text { for } \\
\text { analysis } 1\end{array}$ & 0.393 & 0.047 & 0.433 & 8.310 & 0.000 \\
\hline
\end{tabular}

Source: Authors

We conclude that hypothesis $\mathrm{H} 2$ is confirmed.

In the third case, the influence of factor scores on employees' wages was measured. We started from the following model:

$$
w_{i}=B_{0}+B_{1} f_{i 1}+b_{2} f_{i 2}+\varepsilon_{i}
$$

Where, for $i=n$ observations:

$w_{i}=$ dependent variable (wages)

$b_{0}=y$ intercept (constant)

$B_{1}=$ slope coefficient of predictor $f_{i 1}$

$B_{2}=$ slope coefficient of predictor $f_{i 2}$

$f_{i 1} f_{i 2}=$ the independent variables (regression factor scores $1-2$ )

$\varepsilon_{i}=$ random error 
Based on the value of adjusted $\mathrm{R}^{2}$, a set of two predictor variables explains $87.1 \%$ of the variability of 'wages' (Table 7):

Table 7. Regression model summary (Dependent variable: wages)

\begin{tabular}{|l|c|c|c|c|}
\hline Model & R & R Square & Adjusted R Square & $\begin{array}{c}\text { Std. Error of the } \\
\text { Estimate }\end{array}$ \\
\hline 1 & $.936^{\mathrm{a}}$ & 0.875 & 0.871 & 0.400 \\
\hline \multicolumn{2}{|c|}{ a. Predictors: (Constant), REGR factor score 2 for analysis 1, REGR factor score 1 for analysis 1 } \\
\hline
\end{tabular}

Source: Authors

According to the results, Factor 1 has a statistically significant contribution to the employees' wage growth (Table 8). As for Factor 2, it also has a positive effect on wages growth but it is not statistically significant. If Factor 1 goes up by one point, wages jump by 1.074 .

Table 8. Coefficients ${ }^{\mathrm{a}}$

\begin{tabular}{|c|c|c|c|c|c|c|}
\hline \multirow{2}{*}{\multicolumn{2}{|c|}{ Model }} & \multicolumn{2}{|c|}{$\begin{array}{l}\text { Unstandardized } \\
\text { Coefficients }\end{array}$} & \multirow{3}{*}{$\begin{array}{c}\begin{array}{c}\text { Standardized } \\
\text { Coefficients }\end{array} \\
\text { Beta }\end{array}$} & \multirow{3}{*}{$\begin{array}{c}\mathrm{t} \\
49.179\end{array}$} & \multirow{3}{*}{$\begin{array}{l}\text { Sig. } \\
0.000\end{array}$} \\
\hline & & \multirow{2}{*}{$\frac{B}{2.403}$} & \multirow{2}{*}{$\begin{array}{c}\text { Std. Error } \\
0.049\end{array}$} & & & \\
\hline \multirow{3}{*}{1} & (Constant) & & & & & \\
\hline & $\begin{array}{l}\text { REGR. factor score } 1 \text { for } \\
\text { analysis } 1\end{array}$ & 1.074 & 0.051 & 0.935 & 21.184 & 0.000 \\
\hline & $\begin{array}{l}\text { REGR. factor score } 2 \text { for } \\
\text { analysis } 1\end{array}$ & 0.008 & 0.051 & 0.007 & 0.159 & 0.874 \\
\hline
\end{tabular}

Source: Authors

It is concluded that hypothesis $\mathrm{H} 3$ is partially confirmed. Based on the results, in the companies of the Italian region of Campania, there is a well-established tradition of intrapreneurship strategy. Analyzing the companies, Factor 1 has the dominant influence on all three business indicators, including the organizational and financial aspects. When it comes to the organizational-psychological aspect carried by Factor 2, its impact is significantly smaller and is statistically significant in the case of the company's volume of business and investments.

\section{CONCLUSION}

All intrapreneurs have a developed entrepreneurial spirit within certain limits. Entrepreneurial spirit can certainly be used and developed outside the company through one's own business. However, in order to prevent the entrepreneurial spirit from remaining outside the company's boundaries, it is necessary to provide numerous concessions to the 
intrapreneur, whose benefits outweigh the usefulness of doing business independently. These include unlimited access to financial and other resources for the development of business ideas, adequate working conditions that encourage business autonomy, creativity, risk and tolerance of mistakes, cooperation with other sectors, decentralization of management in the company, pleasant working environment, and other factors. On the other hand, the owner, general manager or the board of directors of a company receive an inexhaustible source of business ideas, loyalty, and profit from a promising intrapreneur. However, in practice, it is very difficult to reconcile the long-term desires and plans of the company's management with the restless business spirit of intrapreneurs, who often leave the company wanting to start their own business or go to competing companies that offer better conditions.

The basic limit of this research is the sample size. Increasing the number of companies in the sample, as well as expanding to some other Italian regions, would increase the quality of the research. In this direction, it would be useful to cross the existing data with companies from one of the northern regions of Italy due to different business cultures. During the COVID-19 pandemic, online work from home in Italy has been used extensively. Thus, the rooms of family apartments have become external offices and workshops of companies. It is too early to say whether this variant of work represents a certain type of intrapreneusrhip, whether it leads to savings, the increased efficiency, or stimulation of work autonomy, leading to the development of individual and small functional teams' creations. However, an interesting area opens up for further research. 


\title{
UTJECAJ STRATEGIJE ZA UNUTARNJE PODUZETNIŠTVO NA POSLOVNE PERFORMANSE TALIJANSKIH TVRTKI
}

\author{
Dr. sc. Vojislav Babić \\ Univerzitet u Beogradu, Institut za sociološka istraživanja \\ Čika Ljubina 18, 11000 Beograd, Srbija \\ Telefon: +38163334067, e-mail: babic.voja@gmail.com \\ Dr. sc. Siniša Zarić \\ Univerzitet u Beogradu, Ekonomski fakultet \\ Kamenička 6, 11000 Beograd, Srbija \\ Telefon: +38163254525, e-mail: sinisha.zaric@gmail.com \\ Dr. sc. Rossana Piccolo \\ Sveučilište u Kampaniji “Luigi Vanvitelli”, Caserta, Italija \\ e-mail: rossana.piccolo@unicampania.it
}

\section{SAŽETAK}

Unutarnje poduzetništvo je decentralizirana strategija upravljanja koja se primjenjuje u velikim i srednjim poduzećima. Strategija omogućava zaposlenicima da koriste svoje poduzetničke vještine u korist tvrtke i zaposlenika. Talentirani zaposlenici imaju priliku stvarati ideje, poduzimati inovativne korake, eksperimentirati, dobiti pristup financijskim i drugim resursima kako bi potaknuli inovativne promjene i rezultate. Tvorac ideje bio je bračni par Pinchot 1978. godine, ali do danas je koncept prošao kroz nekoliko evolucijskih valova (Antoncic, 2020). Strategija unutarnjeg poduzetništva pozitivno utječe na okretnost u tvrtki, povećava učinkovitost, pozitivno utječe na timski duh, povećava produktivnost, smanjuje troškove i povećava profitabilnost. Glavni cilj rada je analizirati razinu prisutnosti unutarnjeg poduzetništva u velikim i srednjim poduzećima u talijanskoj regiji Campania $i$ mjeriti utjecaj parametara unutarnjeg poduzetništva na pokazatelje poslovanja poduzeća. Za potrebe studije stvoren je instrument za mjerenje unutarnjeg poduzetništva. Instrument mjeri prisutnost autonomnih timova u tvrtki, mogućnost preuzimanja poslovne inicijative, brzinu pristupa resursima u svrhu testiranja i realizaciju novih poslovnih ideja, poticanje rizika radi ostvarenja poslovnih ideja, mobilnost resursa unutar tvrtke, stupanj tolerancije menadžmenta radi ostvarenja novih poslovnih ideja zaposlenika, prisutnost sustava nagrađivanja, stupanj menadžerske potpore na svim razinama, broj hijerarhijskih razina u tvrtki i ulogu crowdsourcinga u razvoju unutarnjeg poduzetništva. Nakon faktorske $i$ regresijske analize, faktor 1 ima dominantan utjecaj na sva tri pokazatelja poslovanja, dok faktor 2 ima manji, ali statistički značajan utjecaj na opseg poslovanja i ulaganja tvrtke.

Ključne riječi: unutarnje poduzetništvo, tvrtke, Italija, Campania, poslovni učinak 


\section{LITERATURE}

1. Antoncic, B. (2020). Entrepreneurship/Intrapreneurship, Personality Correlates of. In B.J. Carducci, C.S. Nave, A. Fabio, D.H. Saklofske \& C.Stough (Ed.).The Wiley Encyclopedia of Personality and Individual Differences: Models and Theories (pp.143-147). John Wiley \& Sons Ltd.https HYPERLINK "https://doi.org/10.1002/9781118970843.ch201"://doi. org/10.1002/9781118970843.ch201

2. Ahmad, W., Naing, N. \& Hussein, M. (2007). Selection for Parameter^ by Using Newton-Raphson Method. Statistika, 7(2), 33 - 37. https://ejournal.unisba.ac.id/index.php/statistika/article/ download/987/582

3. Burgelman R.A. (2016). Intrapreneurship. In: Augier M., Teece D. (Ed.) The Palgrave Encyclopedia of Strategic Management. Palgrave Macmillan, London. https://doi.org/10.1057/978-1349-94848-2_392-1

4. Businessfield (2020). Local Business directory, Campania, Italy. Retrieved from https://www. businessified.com/italy/campania

5. Cavallaro, A., \& Gaschi, A. (2019). Intrapreneurship: le 10 competenze dell'Intrapreneur, il dipendente-imprenditore. Retrieved from https://www.economyup.it/innovazione/intrapreneurship-le-10-competenze-dellintrapreneur-il-dipendente-imprenditore/

6. Divakara, S., \& Surangi, H.A.K.N.S. (2021). The Role of Intrepreneurship in the Growth of Smal and Medium Scale Manufactruring Enterprises in Sri Lanka. International Journal of Entrepreneurship, 25 (special issue-1), 1-18

7. Duradoni, M. \& Di Fabio, A. (2019). Intrapreneurial Self-Capital and Sustainable Innovative Behavior within Organizations. Sustainability, 11(2): 322. https://doi.org/10.3390/su11020322

8. Elert N., \& Stenkula, M. (2020). Intrapreneurship: Productive and Non-Productive. Entrepreneurship Theory and Practice. doi:10.1177/1042258720964181

9. Field, A. P. (2005). Discovering statistics using SPSS ( $2^{\text {nd }}$ edition). London: Sage.

10. Fredona, R., \& Reinert, S. (2020). Italy and the Origins of Capitalism. Business History Review, 94(1), 5-38. doi:10.1017/S0007680520000057

11. Guven, B. (2020). The Integration of Strategic Management and Intrapreneurship: Strategic Intrapreneurship from Theory to Practice. Business and Economics Research Journal, 11(1), 229-245. doi: 10.20409/berj.2020.247

12. Hair, J., Black, W., Babin, B. \& Anderson, R. (2010). Multivariate Data Analysis - A Global Perspective. New Jersey: Pearson Education.

13. Hornsby, J., Kuratko, D. \& Zahra, S. (2002): Middle managers' Perception of the Internal Enviroment for Corporate Entrepreneurship: Assesing Measurement Scale. Journal of Business Venturing,17(3), 253-273.

14. Itzkovich, Y., Heilbrunn, S., \& Dolev, N. (2021), “Drivers of intrapreneurship: an affective events theory viewpoint", Personnel Review, Vol. ahead-of-print No. ahead-of-print. https://doi. org/10.1108/PR-09-2019-0483

15. Kumar, S. \& Parveen, R. (2021). Assessing the factors of employees' intrapreneurial behavior: an Indian context. World Journal of Entrepreneurship, Management and Sustainable Development, Vol. ahead-of-print No. ahead-of-print. https://doi.org/10.1108/WJEMSD-12-20200160 
16. Kruger, M. \& Nel, H. (2019). Intrapreneurship. In: Michele Kruger, Hannelie Nel (Ed.). The HYPERLINK "https://www.taylorfrancis.com/books/mono/10.1201/9780429322976/develop ment-women-young-professionals-stem-careers?refld=826e 048b-52be-4536-8017f25b80012d68" Development of Women and Young Professionals in STEM Careers, $1^{\text {st }}$ Edition, ImprintCRC Press. https://doi.org/10.1201/9780429322976

17. Millar, R.B. (2011). Maximum Likelihood Estimation and Inference: With Examples in R, SAS and $A D M B$. New York: John Wiley and Sons.

18. Mumford, M., Elliott, S. \& Martin, R. (2020). Intrapreneurship and Firm Innovation: Conditions Contributing to Innovation. In Gielnik, M.M., Cardon, M.S., \& Frese, M. (Ed.). The Psychology of Entrepreneurship: New Perspectives ( $1^{\text {st }}$ ed.). Routledge. https://doi.org/10.4324/ 978100313 7573, New York, Routledge, Chapter 7. https://doi.org/10.4324/9781003137573

19. OECD (2020). Financing SMEs and Entrepreneurs 2020: An OECD Scoreboard. Paris, OECD Publishing, https://doi.org/10.1787/061fe03d-en.

20. Pinchot, G. \& Pinchot, E. (1978). Intra-corporate entrepreneurship. School of Entrepreneurs, Tarrytown

21. Radman,S.(2019).Intrapreneurship.Retrieved from https://www.researchgate.net/publication/332728302

22. Sijde, P.C. van der, Veenker, S., \& During, W. (2013). Intrapreneurship in SMEs: about the role of management and R\&D. European Journal of Business and Social Sciences 1(11), 24-30. 